\title{
Competition in the Grain Belt Meatpacking Sector after World War II
}

\author{
JON K. LAUCK
}

FOR MORE THAN A CENTURY, American farmers have identified concentrated economic wealth-the monopoly problem-as a threat to their economic future and to the future of the republic. They feared that the concentration of wealth stifled competition and warped and destabilized democratic political institutions. A familiar target of those concerned about economic concentration and monopoly was American meatpacking, known as "the greatest trust in the world." But a careful review of the post-World War II meatpacking industry reveals that as concentration declined, redefined itself, and then reemerged in a different form, one factor remained constant: intense competition within the industry. Rival firms talked of "waging war" with one another, the demise of uncompetitive firms was widespread, and many of the changes in plant size and concentration level were justified for economic reasons. ${ }^{1}$

In the past decade a substantial body of scholarship has emerged-much of it in the Annals of lowa-exploring the twentieth-century meatpacking industry. That scholarship explains the emergence and unraveling of the pattern bargaining system built by meatpacking unions in the 1930s and 1940 s

1. Robert M. Aduddell and Louis P. Cain, "Public Policy toward 'The Greatest Trust in the World," Business History Review 55 (1981), 217; W. Smith Greig, "The Changing Structure of the Food Processing Industry: Description, Causes, Impacts and Policy Alternatives," Bulletin 827, September 1976, College of Agriculture Research Center, Washington State University, 15-17.

THE ANNALS OF IOWA 57 (Spring 1998). OThe State Historical Society of Iowa, 1998. 
and describes the effects of the transformation of the industry in the 1970 s and 1980 s on workers and their communities. ${ }^{2}$ My review of the competitive features of postwar meatpacking extends the conversation begun in that literature beyond the shop-floor and beyond the question of meatpacking's effects on workers and small towns and shows that whatever ill effects can be attributed to the transformation of the postwar meatpacking industry may be due to intense competition within the industry, not its absence. While this review should contribute to a broader understanding of the grain belt political economy, it is especially relevant for those interested in the history of Iowa, since large-scale livestock production has played and continues to play an important role in the state's political economy, and since two of the prime players in the transformation of the industry nationwide-Cargill and Iowa Beef Processors (IBP)-originated in lowa.

DURING THE DEBATE over the Sherman Antitrust Act of 1890, Congressman Richard Bland of Missouri argued, "there is no trust in this country that today is robbing the farmers of the great West and Northwest of more millions of their hardearned money than this so-called Big Four beef trust of Chi-

2. Roger Horowitz, "'It Wasn't a Time to Compromise': The Unionization of Sioux City's Packinghouses, 1937-1942," Annals of Iowa 50 (1989/1990), 241-68; Mark A. Grey, "Turning the Pork Industry Upside Down: Storm Lake's Hygrade Work Force and the Impact of the 1981 Plant Closure," Annals of Iowa 54 (1995), 244-59; Bruce Fehn, "'The Only Hope We Had': United Packinghouse Workers Local 46 and the Struggle for Racial Equality in Waterloo, Iowa, 1948-1960," Annals of Iowa 54 (1995), 185-216; Gregory R. Zieren, "A Century of Meatpacking and Packinghouse Labor in Chicago: A Review Essay," Annals of Iowa 49 (1989), 692-709; idem, "If You're Union, You Stick Together': Cedar Rapids Packinghouse Workers in the CIO," Palimpsest 76 (1995), 30-48; Wilson J. Warren, "The Welfare Capitalism of John Morrell and Company, 1922-1937," Annals of lowa 47 (1984), 497-517; idem, "The Heyday of the CIO in Iowa: Ottumwa's Meatpacking Workers, 1937-1954," Annals of Iowa 51 (1992), 363-89; idem, "When 'Ottumwa Went to the Dogs': The Erosion of Morrell-Ottumwa's Militant Unionism, 1954-1973," Annals of Iowa 54 (1995), 217-43; Shelton Stromquist and Marvin Bergman, eds., Unionizing the Jungles: Labor and Community in the Twentieth-Century Meatpacking Industry (Iowa City, 1997). 
cago." ${ }^{\prime \prime}$ Thirty years later the newly founded Federal Trade Commission (FTC) concluded that the meatpackers' market power and efforts to diversify indicated that they were attempting to "monopolize" the nation's food supply. The resulting 1920 consent decree ruled that the big meatpackers could not own any interest in stockyards, terminal railroads, or market newspapers or journals; use their networks to deal in non-meat products or own a controlling interest in nonmeat products; sell meat at the retail level; or own warehouses. In 1932 the U.S. Supreme Court ordered the major packers to comply with the decree."

In the postwar period the infamous American meatpacking industry changed dramatically, rendering the consent decree meaningless. Most of the older firms that had dominated the industry in earlier decades and prompted so much public scrutiny went under or were acquired by ascendant firms or conglomerates. Economic pressure also stemmed from concentrating power in the feeding and retailing sectors, diminishing per capita demand, competition from other meats, a growing level of imports, the emergence of a series of new firms with plants closer to beef supplies that could take ad-

3. Gary D. Libecap, "The Rise of the Chicago Packers and the Origins of Meat Inspection and Antitrust," Economic Inquiry 30 (1992), 244, 246, 248, 258-59. Libecap doubts the arguments of farmers and smaller packers and simply sees them as victims of structural change in a competitive economy. His argument, then, casts doubt on the notion that the intent of the Sherman Act was competition and efficiency. For more on this view, see Thomas W. Hazlett, "The Legislative History of the Sherman Act Re-Examined," Economic Inquiry 30 (1992), 263-76.

4. Aduddell and Cain, "Public Policy," 220, 238-40. Some historians see the emergence of the Big Four meatpackers resulting from an "inherent" advantage conferred by the nature of the industry. See Thomas K. McGraw, "Rethinking the Trust Question," in Regulation in Perspective: Historical Essays, ed. Thomas K. McGraw (Cambridge, MA, 1981), 24. If true, the advantages of the arrangements quickly dissipated after the war, and the meatpacking industry was soon riven by crises that created a new set of competitive problems. See Mary Yeager, Competition and Regulation: The Development of Oligopoly in the Meat Packing Industry (Greenwich, CT, 1981), 242. In 1948 the Department of Justice began an effort to break Armour and Swift into five companies each and Cudahy and Wilson into two each. The effort was abandoned in 1954. In 1956 a federal judge refused to modify the 1920 consent decree. Jimmy M. Skaggs, Prime Cut: Livestock Raising and Meatpacking in the United States, 1607-1983 (College Station, TX, 1986), 187-88. 
vantage of lower labor costs, a productivity "revolution," and a degree of farmer organization. The many structural changes in the industry indicate its dynamism and high degree of competition.

One of the checks on the meatpackers was the growing power and concentration of the feeding industry. Previously, much of the final feeding of slaughter cattle had taken place on small farms scattered around the country. In 1962 twothirds of cattle marketed for slaughter still came from feedlots with a capacity of less than 1,000 head, and most of the other one-third came from feedlots with a capacity between 1,000 and 1,600 head. By 1973, however, more than two-thirds of the cattle were fattened on large commercial feedlots-20 percent on feedlots with a capacity greater than 32,000 head. Many of the new operations were located in the central and southern plains as opposed to the more traditional Corn Belt; Iowa Beef Processors co-chairman Currier Holman warned Senator Dick Clark (D, IA) that Iowa risked losing its feeding industry. ${ }^{5}$ By 1982,381 feedlots with a capacity of at least 8,000 head marketed more than half of the fed cattle in the 23 leading states. ${ }^{6}$ By 1995, more than 90 percent of beef cattle were marketed from feedlots with a capacity of at least 1,000 head, prompting greater packer competition among a dwindling number of larger suppliers. An internal U.S. Department of Agriculture (USDA) memorandum in the 1960s estimated that larger feedlots could receive as much as $\$ 12$ per hundredweight above market price from packers.

5. C. Edward Harshbarger and Sheldon W. Stahl, "Economic Concentration in Agriculture-Trends and Developments," Monthly Review, Federal Reserve Bank of Kansas City (April 1974), 23; Currier J. Holman to Richard Clark, 12 December 1972, Richard Clark Papers, Special Collections, University of Iowa Libraries, Iowa City.

6. Roughly 90 percent of cattle located West of the Missouri River were fed on the large lots $(1,000+)$; in Iowa and Nebraska the rate dropped to about 40 percent, and to only 15 percent in Ohio, Indiana, Illinois, Wisconsin, and Minnesota. Gwen Quail et al., "The Impact of Packer Buyer Concentration on Live Cattle Prices," May 1986, Working Paper Series 89, N.C. Project 117, 3.

7. Teresa Glover and Leland Southard, "Cattle Industry Continues Restructuring," Agricultural Outlook (USDA, Economic Research Service), December 1995, 14; Willard W. Cochrane to Orville Freeman, 20 March 1964, Orville Freeman Papers, Minnesota Historical Society, St. Paul, MN. 
The increasing importance of the larger feedlots meant that more and more cattle were sold directly from feedlot to packer, bypassing the terminal market stage. From 1950 to 1964, the percentage of cattle that packers bought in terminal markets dropped from 75 to 37 percent and the percentage of hogs from 40 to 24 percent. In 1984 packers purchased 79 percent of their beef supplies directly from feedlots and only 7 percent from terminal markets. The level of direct packer involvement in feeding, always quite small, was shrinking: by 1980-1982 the percentage of packer-fed cattle dropped to 4 percent from 7 percent in the $1960 \mathrm{~s}^{8}$

The food retailing sector also emerged as a powerful constraint on the market power of the packers. At the time of the large-scale FTC investigation from 1917 to 1919, the packers operated their own branch houses and sold 93 percent of all fresh and cured (wholesale) meat. As a result, grocers had little influence on the major packers.' After the consent decree prohibited packer involvement in retailing and after the rise of chain retailers, however, this relationship changed dramatically. Grocery stores with meat increased their share of the market from 31 percent in 1929 to 74 percent in 1954, and from 1920 to 1958 the percentage of grocery sales accounted for by chains and cooperatives jumped from 11 to 85 percent. The power of supermarkets and food chains, some of whom started to pack their own beef, even sparked concerns about a "new monopoly." Part of the reason for the minimal backward integration into food processing by chain grocery stores is the low profit margins in meatpacking and the already com-

8. "Food from Farmer to Consumer," Report of the National Commission on Food Marketing (Washington, DC, 1966), 22; Samuel H. Logan, Lisa J. Steinmann, and Donald E. Farris, "Economics of Meat Processing in the United States," in Chester O. McCorkle Jr., ed., Economics of Food Processing in the United States (San Diego, 1988), 247-48; Bruce W. Marion, The Organization and Performance of the U.S. Food System (Lexington, MA, 1986), 126. A study of fifteen western states in the 1960s indicated that most of the feedlots were owned by independent feeders, ranchers, and farmers and that packers and marketing firms controlled only about 12 percent of feedlot capacity in lots of 1,000 or more head. Report of the National Commission on Food Marketing, 24.

9. Aduddell and Cain, "Public Policy," 231-32. 
manding market power of the chain grocery stores. Competition did stiffen, however, to the degree to which grocery chains did manufacture their own products. In the mid-1960s between 8 and 9 percent of food sales were from products manufactured by grocery chains; Safeway, for example, owned three meat processing plants. The number is not higher because processing is generally "competitive and efficient," and therefore backward integration by grocers would not yield extracompetitive profits.

A further check on the market power of the food processing sector stemmed from the power of restaurants. In 1967, 31 percent of total food sales were classified as "away-fromhome." These included "public eating places," schools, hospitals, colleges, the military, and others. The power of food retailers such as restaurant chains, coupled with independent and chain groceries, would place steady pressure on packers to keep prices competitive. As Mary Yeager notes, "In this changed world of retailing, where buyers had the power to choose their suppliers and enforce competitive bidding, the large packers had no special advantages over the smaller, more specialized packing concerns." ${ }^{11}$ A\&P's success at securing lower prices from food manufacturers in the late $1940 \mathrm{~s}$ and Rath's and IBP's jockeying for Safeway's business in the 1970 s indicate the growing influence of food retailers. FTC studies in the 1960s took note of this growing power; and in the 1970s, during House Small Business Committee hearings, one economist noted that John Kenneth Galbraith and other advocates of building the market power of sectors adjacent to concentrated sectors should applaud the changes in both

10. Robert M. Aduddell and Louis P. Cain, "The Consent Decree in the Meatpacking Industry, 1920-1956," Business History Review 55 (1981), 364; John T. Schlebecker, Cattle Raising on the Plains, 1900-1961 (Lincoln, NE, 1963), 224; James Abourezk, speech to Consumer Assembly, 30 January 1975, James Abourezk Papers, Richardson Library, University of South Dakota, Vermillion; Greig, "Changing Structure," 13-14. The quote is from R. B. Heflebower, "Mass Distribution: A Phase of Bilateral Oligopoly or of Competition," Papers and Proceedings of the Sixty-Ninth Annual Meeting of the American Economics Association, December 1956.

11. Yeager, Competition and Regulation, 240. 
food retailing and cattle feeding and the constraints they placed on packers. ${ }^{12}$

In addition to the market strength of feeders, retailers, and restaurants, the tenuous aggregate demand for meat also constrained potential monopoly power among packers. In 1950, for example, average beef consumption was 71 pounds, but after inflation cut purchasing power, consumption declined to 63 pounds in 1951. In 1955 consumption reached the "gastronomical feat" of 91 pounds per person, but an intervening urban recession reduced the level of consumption to 81 pounds in 1959. Per capita consumption of beef peaked in 1976 at 127 pounds per year-twice the 1950 level-but during 1979-81 it dropped to 104 pounds. Consumer sensitivity to prices prevented meatpackers from raising prices to monopoly levels, since the overall effect on demand could be so negative. A manager of economic research at Wilson \& Co. conceded that changes in demand were driven by consumer sensitivity to "changes in income and inflation." 13

Beef also faced increasing competition from chicken and fish as reports about carcinogens in beef linked heart disease and strokes to red meat consumption. When Giant Food, Inc., ran advertisements ridiculing the price of red meat and pro-

12. Willard Williams, "Small Business Problems in the Marketing of Meat and Other Commodities (Part 4, Changing Structure of Beef Packing Industry)," Hearings before the Subcommittee on SBA and SBIC Authority and General Small Business Problems of the Committee on Small Business, House, 96th Cong., 1st sess. (Washington, DC, 1979), 3 (hereafter cited as House hearings); Report of the National Commission on Food Marketing, 26; D. I. Padberg, "Economic Theory of Bargaining in Agriculture," Jourmal of Farm Economics 45 (1963), 1281; Roger Horowitz, "Meatpacking as Paradigm? Labor and the Dynamics of Industrial Change in Twentieth-Century America," 14, Research Seminar no. 15, February 1994, Center for the History of Business, Technology, and Society, Hagley Museum and Library, Wilmington, DE; John M. Connor et al., The Food Manufacturing Industries: Structure, Strategies, Performance, and Policies (Lexington, MA, 1985), 104. For packer competition for grocery store business (in this case Safeway), see J. F. Lambert to H. E. Williams, n.d., Rath Papers, Iowa State University, Ames; John Kenneth Galbraith, American Capitalism: The Concept of Countervailing Power (Boston, 1952).

13. Schlebecker, Cattle Raising, 204, 224; Richard T. Crowder, "The Economic Outlook for Beef Cattle," 16, Council of Economic Advisors Records, Gerald Ford Presidential Library, Ann Arbor, MI; Marion, Organization and Performance of the U.S. Food System, 124. 
moting products such as "boneless shad," senators from livestock-dependent states attacked the company. Carl Curtis ( $R$, NE) tried to interest the FTC in investigating Giant Food, because the company charged more for "boneless shad" than for shad fillets, exposing the company's marketing ploy by pointing out that there was no such thing as "boneless shad." Curtis's office also pointed out that Giant charged "excessive prices for rock fish," which they sold at 40 cents per pound wholesale but $\$ 1.89$ "whole or uncleaned," a 450 percent markup. Both efforts sought to discredit fish products that Curtis and others feared would be substituted for beef. By 1987 it seemed that the battle against beef substitutes was lost, as per capita consumption of chicken actually surpassed beef for the first time. Some predicted that beef consumption would decline to 50 pounds per year by the year 2000. A Nebraska newspaper reported after the recent "Beef States Summit" in Omaha that demand for cattle would continue to be a problem "if consumers continue to choose pork and poultry from grocery store shelves rather than beef." With demand tenuous and the substitution of other meats relatively easy, monopoly pricing of beef would have been extremely difficult and extremely foolish, driving away consumers who had other options. ${ }^{14}$

The "shock" in the demand for beef was so severe that from 1979 to 1986 real beef prices had to decline more than 30 percent to maintain a constant level of beef sales. As a result, beef herds were liquidated in the United States. Herds shrunk from about 132 million head in 1975 to about 100 million fifteen years later, creating a 20 to 30 percent excess capacity in packing plants. Pork also suffered from demand problems. In the early seventies a vice-president at Oscar Mayer noted that in the late 1940 s pork had commanded 40 percent of the red meats and poultry market but slipped to 28 percent by 1970 . The inflation of the early. 1970s, which produced food price increases of as much as 15 percent in 1973 alone, also triggered

14. Carl Curtis to Miles Kirkpatrick, 13 April 1972, short synopsis, no date, and Don to Office, 15 April 1972, both in Carl Curtis Papers, Nebraska Historical Society, Lincoln; "IBP and the U.S. Meat Industry," Harvard Business School Case 9-391-006, revised 4 April 1995, 3; Skaggs, Prime Cut, 168; Lincoln Journal and Star, 10 July 1996. 
protests, boycotts, and the organization of a broad consumer movement that was quick to criticize what its supporters viewed as high food prices and to urge consumers to substitute other products for meat. Media coverage of food prices increased tenfold in 1972, doubled again in 1973, and in March 1973 Congressman Benjamin Rosenthal (D, NY) called for a national consumers' boycott of beef. ${ }^{15}$

The power of packers to increase domestic prices, a key indicator of market power, was also thwarted by a growing level of imports in the postwar period. Beef and veal imports expanded from 2 percent of domestic supply in 1955 to 9 percent by 1963 . Between 1960 and 1963 meat imports increased by about 900 million pounds, depressing hamburger prices by at least 10 percent. Farmers shared packers' concerns about imports to the extent that they outweighed concerns about packer fair play. In 1952, according to John Schlebecker, even a "piddling 40 million pounds of commercial grade beef" from New Zealand "offended the delicate sensibilities of the cowboys." This concern partially explains why Congress passed the Meat Import Act in 1964, which reduced imports by 8 percent in the law's first year and made import restrictions the "primary means" of price support by the federal government. For the next decade, the government cobbled together an import program mixing quotas, voluntary export restraints on foreign traders, and open trade in an attempt to manage market con-

15. Wayne D. Purcell, "Economics of Consolidation in the Beef Sector: Research Challenges," American Journal of Agricultural Economics 72 (1990), 1212, 1214; John M. Connor et al., "Economic Forces Shaping the FoodProcessing Industry," American Journal of Agricultural Economics 67 (1985), 1137; Skaggs, Prime Cut, 184; Harshbarger and Stahl, "Economic Concentration," 21; Gilbert C. Fite, American Farmers: The New Minority (Bloomington, IN, 1981), 140; Wall Street Journal, 15 October 1973; John Mark Hansen, Gaining Access: Congress and the Farm Lobby, 1919-1981 (Chicago, 1991), 191.

16. Walter Hasty, "Recent Legislative Developments: Beef Imports and the Cattle Industry," Supplement \#1, Legislative Analysis Memorandum \#56-4, 10 February 1964, National Farmers Union-National Council of Farmers Cooperatives Papers, Iowa State University, Ames; J. W. Freebairn and Gordon C. Rausser, "Effects of Changes in the Level of U.S. Beef Imports," American Journal of Agricultural Economics 57 (1975), 687-88; Report of the National Commission on Food Marketing, 28; Schlebecker, Cattle Raising, 220-21. 
ditions. Cattle producers were often furious with the results, which they felt were too often manipulated by the State Department. The Nixon White House paid close attention to the connection between foreign trade and meat prices. Taking particular notice of how high meat prices contributed to the defeat of Prime Minister Harold Wilson in England in 1970, President Nixon commented, "We can't let that happen to us. ${ }^{\text {"17 }}$

The extent of imports remained controversial. As one farmer put it, the free trading "boys [weren't] too popular around the livestock barns" in those years. ${ }^{18}$ Competitive pressure continued, as imports still totaled about 9 percent of commercial production in the 1980s (Australia accounted for about one-half, New Zealand about one-quarter, and Argentina, Canada, and Brazil rounded out the total). By contrast, exports totaled only a little more than 1 percent of commercial production (most of which went to Japan) in 1983. In 1988 the chance of greater export growth was further constrained when the European Economic Community (EEC) banned American beef raised with growth hormones. ${ }^{19}$ Greater access to world markets, favorable exchange rates, and lower prices boosted exports to 7 percent of total production by 1995, however,

17. L. William Seidman to Gerald Ford, 12 December 1975, L. William Seidman Papers, Gerald Ford Presidential Library, Ann Arbor, MI; Wray Finney (American National Cattlemen's Association) to Gerald Ford, 27 August 1976, and Henry Kissinger to Wray Finney, 5 October 1976, ibid.; Clifford P. Hansen to Donald Rumsfeld, 18 February 1972, Earl Butz Papers, Purdue University, West Lafayette, IN; Homer Ayres to Tony Dechant, 19 December 1978, National Farmers Union Papers, Archives, University of ColoradoBoulder; Gary Clyde Hufbauer, Diane T. Berliner, and Kimberly Ann Elliott, Trade Protection in the United States (Washington, DC, 1986), 323, 325; Marion, Organization and Performance of the U.S. Food System, 130; Theodore H. White, The Making of the President, 1972 (New York, 1973), 65. American restrictions on meat imports eased slightly after the conclusion of the Tokyo Round of the GATT in the late 1970s. James P. Houck, "U.S. Agricultural Trade and the Tokyo Round," Law and Policy in International Business 12 (1980), 287. Significant reductions in international restrictions on agricultural trade would not be approved until the recent Uruguay Round. See Jeffrey J. Steinle, "The Problem Child of World Trade: Reform School for Agriculture," Minnesota Journal of Global Trade 4 (1995), 333-60.

18. Joe E. Owens to Senator Richard Clark, September 1975, Clark Papers.

19. Logan, Steinmann, and Farris, "Economics of Meat Processing," 252-53; "IBP and the U.S. Meat Industry," 6. 
nearly equalizing the amount of imports and exports. Within the next seven years, one of the leading cattle slaughterers, IBP, hopes to boost foreign sales to 25 percent of its total sales. ${ }^{20}$

At times, packers also competed vigorously for supplies of cattle and hogs coming directly from farmers. The National Farmers Organization (NFO), which organized holding actions in the 1950s and 1960s in order to boost farm prices, successfully disrupted packers' traditional supplies. The Hormel plant in Austin, for example, lost the supplies of local farmers, which were organized through NFO collection points, to Morrell in Sioux Falls and Ottumwa and Swift in St. Paul. In the spring of 1968 Rath Packing agreed to buy 1,200 hogs daily from the NFO's country collection points, paying a "local country price" plus 15 cents -5 cents for arranging the delivery and 10 cents for the collection point operators. The packers who signed contracts with the NFO hoping to reduce procurement costs may have been put at a competitive disadvantage in the long run. A Hygrade official noted the competitive disadvantage of NFO contracts shortly before the company sold out to IBP in 1981: "What we can't afford to do is pay more than our competitors." Although the overall impact of the NFO is unclear, it did result in uneven procurement costs among packers-with those who bought from organized farmers paying more than those who did not-underscoring the competitive pressures on many packers. ${ }^{21}$

20. Glover and Southard, "Cattle Industry Continues Restructuring," 15; Value Line Investment Survey, 16 February 1996, part 3, Ratings and Reports, Edition 10, 1480. For information about the price reduction, increased competition, and increased demand resulting from liberalization and deregulation of Zen-Noh, the Japanese super-cooperative, see "Zen-Noh: 'I Love Gyu (Beef)'-New Challenges for the Beef Business," 26 October 1993, Harvard Business School Case 9-594-037. The U.S. signed free trade agreements in the late 1980s and early 1990s with the countries to which it exports the most agricultural products: Japan, Canada, and Mexico.

21. Rochester Post-Bulletin, 24 March 1966; Ottumwa Courier, 5 May 1971; Farm Journal 101 (January 1977), 37; Walt Hackney, statement, 10 July 1979, National Farmers Organization Papers, Iowa State University, Ames; Chicago Sun-Times, 7 September 1962; D. W. Wright to Wm. M. Cameron, 14 August 1967, D. W. Wright, memo, 31 August 1967, Bernard W. Ebbing to Gene Potter, 1 May 1968, and Preliminary Prospectus, 29 January 1964, all in Rath Papers; Jon Lauck, "The National Farmers Organization and Farmer Bargaining Power," Michigan Historical Review (forthcoming Fall 1998). 
Farmers also entered the market in direct competition with the meatpackers, a clear indication of a weak market position and of an inability to set prices or restrict entry. The farmers cooperative Farmland Industries bought the Crawford County Packing Company in Denison, Iowa, in 1959 and created the subsidiary Farmbest, Inc. to operate the plant starting in 1962. In 1963 it opened another hog plant in Iowa Falls. By 1967, the hog operation included sixteen buying stations, slaughtering, cutting, ham and bacon processing, and the marketing of FarmKing, Farmbest, and Country Manor brands. Farmland soon constructed another $\$ 18$ million hog slaughtering facility in Crete, Nebraska. In 1965 Farmland helped dedicate a cooperative cattle slaughtering plant in Garden City, Kansas, known as the Producers Packing Company. In three years the independent cooperative, then with a kill capacity of 700 daily, merged with Farmland. As with many packers during the period, the facility lost money every year from 1965 to 1968. In 1970 the Farmland board of directors voted to create Farmland Foods, Inc., a new corporation, to handle the meat business. By 1973 Farmland, which wanted farmers to be able to control their hogs from "first oink to the dining table," processed 10 percent of the hogs raised in Iowa. Cooperative patronage funds paid to farmers in 1971 totaled $\$ 1.22$ per hog and $\$ 2.48$ per head of cattle. In leaner years, however, no patronage refunds could be paid at all. ${ }^{22}$

EVEN MORE COMPELLING EVIDENCE of competition in the meatpacking sector than that related to the increased power of the feeding and retailing sectors, diminished demand, and increased imports stems from the massive structural "re-engineering" of the industry after World War II. In 1950 the traditional Big Four firms controlled 52 percent of the total sales in the industry. By 1964, this number had dwindled to 28

22. Gilbert C. Fite, Beyond the Fence Rows: A History of Farmland Industries, Inc., 1929-1978 (Columbia, MO, 1978), 260-61, 276, 306-14. The National Farmers Union estimated that the cost of entering the meatpacking market with farmer-owned packing plants was not prohibitive. Division of Community Development Services, "New Opportunities for Farmer Cooperatives," 15 December 1964, National Farmers Union Papers. 
TABLE 1

TOTAL SALES OF BIG FOUR MEATPACKERS (MILLIONS OF DOLLARS)

\begin{tabular}{lccccc}
\hline & Swift & Armour & Wilson & Cudahy & Total \\
\hline 1952 & 2,593 & 2,184 & 826 & 563 & 6,166 \\
1962 & 2,495 & 1,859 & 711 & 313 & 5,378 \\
\hline
\end{tabular}

TOTAL SALES OF LITTLE FIVE MEATPACKERS (MILLIONS OF DOLLARS)

\begin{tabular}{ccccccc}
\hline & $\begin{array}{c}\text { Oscar } \\
\text { Mayer }\end{array}$ & Hormel & Morrell & Rath & Hygrade & Total \\
\hline 1952 & 217 & 306 & 292 & 253 & 137 & 1,207 \\
1962 & 270 & 385 & 571 & 273 & 456 & 1,955 \\
\hline
\end{tabular}

SOURCE: Lawrence A. Danton, "The Decline of an Oligopoly: Changes in the Meat Packing Industrial Structure," The Rocky Mountain Social Science Journal 5 (1968), 43-44.

percent and by 1972 to 25 percent. The Big Four oligopoly shattered after the war with the growth of the "little five" (see table 1). Other, more cost-efficient rivals, such as Iowa Beef Processors and MBPXL also emerged. By 1982 the top-four concentration ratio had crept back to 35 percent, but involved new firms. As the leadership of IBP argued, the "entire industry [had been] revolutionized! ${ }^{\prime 23}$

The "shake-out" triggered many plant closings and many industry mergers; between 1967 and 1982 the number of meatpackers with twenty or more employees dropped from 955 to 668. In 1967 the conglomerate Ling-Temco-Vaught acquired Wilson \& Co. and decided to close many of its beef plants, including plants in Albert Lea, Cedar Rapids, Oklahoma City, and Louisville. Armour, the second-largest meatpacker after World War II, was "gobbled up" by Greyhound Corporation in 1970 and made a failed attempt to expand into fast food. Between 1956 and 1963, Armour closed sixteen plants, including

23. Quote from economist Luther Tweeten, Columbus Dispatch, 18 February 1996; Logan, Steinmann, and Farris, "Economics of Meat Processing," 250-51; Dale Tintsman and Robert L. Peterson, Iowa Beef Processors, Inc.: An Entire Industry Revolutionized! (New York, 1981). 
plants in Sioux City, Green Bay, Omaha, Chicago, and Fort Worth. Hormel, another of the nation's largest meatpackers, leased its slaughtering plants and attempted to diversify into a "food company." Hormel succeeded in reducing its dependence on meat, and its ratio of branded, value-added products rose from 30 percent of total sales in 1979 to 75 percent by 1989. In 1980 Swift's owner Esmark closed plants representing 70 percent of its steer and heifer slaughter, including its plant in Des Moines. In the same year Monfort closed its Greeley plant, where only two years before it had conducted its entire beef slaughter. Also in 1980, Farmland Industries closed its plant in Garden City, Kansas, which had slaughtered 285,000 head annually. In 1973 John Morrell, acquired by AMK in 1967, closed its Ottumwa plant-the company's original headquartersand for years teetered on the brink of closing its Sioux Falls and Sioux City plants. Such changes prompted Dick Knowlton, head of Hormel, to comment, "People talk about the steel industry being devastated. What happened to the meat industry makes that look like a Sunday school picnic." A House Small Business Committee report concluded in 1980 that "few industries in the nation today ... are in such turmoil. ${ }^{24}$

The most successful-and aggressive-of the new firms entering the meatpacking market was Iowa Beef Processors, a company that started with the help of a Small Business Administration loan in 1960 in Denison, Iowa. IBP often bid up the price of live cattle in an area to divert supplies from the older packers. As one former IBP official acknowledged, "The goal was to be the lowest cost producer [and] the lowest cost slaughterer, to enable us to pay a quarter a cent a pound more for desirable cattle and take them away from the competition."25 IBP also bought large quantities of carcasses from the older packers, waited for their distribution systems to erode, then stopped buying from them. Unable to afford live cattle, and without a market, the older firms folded. In 1975, 45 percent of

24. Horowitz, "Meatpacking as Paradigm?" 20; Warren, "When 'Ottumwa Went to the Dogs," 240-44; "George A. Hormel \& Company," Harvard Business School Case 9-591-026, 7 May 1991, 3 (Knowlton quote); House hearings, Part 3, 35-42, 45-46.

25. Hughes Bagley, House hearings, Part 5, 22. 
Dubuque Packing's carcasses went to IBP, 25 percent of Hyplains' (Kansas), 30 percent of Midwestern's, 25 percent of Platte Valley's (Nebraska); and 50 percent of Amarillo Packing's. Many of these carcasses were further processed into "boxed beef," or packer-packaged individual cuts of meat ready for sale in grocery stores. IBP's share of boxed beef sales approached 50 percent of total sales in the mid-1970s. ${ }^{26}$

IBP also tried to reduce the market share of its meatpacking rivals by offering discounts to large retailers, a risky strategy given the Justice Department's quick action against John Morrell for offering gifts to retailers in 1965. At about the time Rath Packing Company was seeking Safeway's business, IBP offered discounts: 50 cents per hundredweight if it bought 500 cattle per week; 75 cents for 750; a dollar for 1,000. IBP officials knew they risked Robinson-Patman Act violations for price discrimination for not offering discounts to distributors also. Aside from potential objections from distributors, they knew that any discounts required a cost-saving justification, so they concluded that "we should have a memo in our files reaching the conclusion that a cost savings could be realized by purchases in the quantities for which we propose to offer discounts." The company made a series of internal attempts to justify the discounts-some concluding the cost saving to be more than a dollar per head if twelve carloads ( 972 head) were ordered instead of one (81 head). Many of the company's plans had to be reexamined when the Packers and Stockyards Administration started paying more attention to pricing practices and required that distributors be given equal treatment. IBP's attorneys feared the negative publicity of a RobinsonPatman violation and considered the possibility of trebledamage lawsuits too risky, so the company terminated its discounts until an independent cost study could be done. ${ }^{27}$

26. Willard Williams, citing a National Economic Research Associates, Inc. report, House hearings, Part 4, 32-33; Hughes Bagley, House hearings, Part 5, 9; Skaggs, Prime Cut, 195. IBP did not start breaking down carcasses into boxed beef until they bought the Dakota City plant in 1967. Tintsman and Peterson, Iowa Beef Processors, 9.

27. Hughes A. Bagley to W. L. Heubaum, 2 August 1972, internal IBP memo, 1, House hearings, Part 5, 50, 125; Don Hartstack to Stanley Feldman, 10 October 1972, internal IBP memo, 5, House hearings, Part 5, 140; National 
In addition to volume discounting, IBP aggressively sought to undercut the price of its rivals. The only way to promote "desirable behavior" among customers, as one IBP vice-president saw it, was to give them a reason based on price. He argued that IBP's price reduction must be impressive enough to give retailers an incentive to switch to IBP, or, following the logic of oligopolistic interdependence advanced by some antitrust scholars, "no volume will shift hands and everyone will be less profitable. ${ }^{\prime 28}$ Smaller packers accused large packers such as IBP of "selling below cost" long enough to drive them out of business and subsidizing the effort with profits from other divisions of the conglomerate. They even asked the Packers and Stockyards Administration to force companies to file reports on individual plants since aggregated reports failed to detect "unfair competitive practices or acts of monopoly."

During hearings of the House Small Business Committee in 1980, a former IBP executive came forward with testimony and documents outlining IBP's market strategies. Hughes Bagley, who had been terminated by IBP and was employed by Spencer Foods at the time of his testimony, believed that "somebody somehow had to stand up and be counted, or IBP was going to swallow up all of its smaller competition, including my new employer" as part of a "massive takeover by IBP of the packing industry." Bagley testified that IBP became "overly zealous in its attempts to control and monopolize the packing industry" and that "the idea of market domination was discussed continuously by Mr. Holman [the co-chairman] and

Provisioner 161 (5 July 1969) no. 1; J. F. Lambert to H. E. Williams, 4 April 1973, Rath Papers; W. L. Heubaum to C. J. Holman et al., 27 April 1973, 1-2, House hearings, Part 5, 144-45.

28. Perry Haines to Formula Pricing Committee, 8 December 1975, House hearings, Part 5, 11. Oligopolistic interdependence is the theory that firms will not cut prices lest they trigger a price war, leaving all firms in the market less profitable.

29. Open letter to the Livestock and Meat Industry, Western States Meat Packers Association, Inc., 21 May 1969, Rath Papers. "Under present arrangements, conglomerate and integrated firms publish financial data only for their total activities and thus disclose no information about operations in particular fields such as their specialized competitors regularly publish." Report of the National Commission on Food Marketing, 106. 
others at IBP. It was almost as if we were waging war against our competitors. It was felt that the best way to achieve market domination was to control the industry at the production level because then we could control the industry at the retail level. Mr. Holman continually stated that the balance of marketing power could be shifted from the retail chains to IBP." ${ }^{\prime 30}$

Cargill and ConAgra also emerged during this period as important packers. Cargill emerged as a major player in 1978, when it acquired MBPXL, the firm that had resulted from the merger of Missouri Beef Packers and Kansas Beef Industries in 1974. By 1979, Cargill was slaughtering 1.7 million steers and heifers; a year later the firm started a new plant in Dodge City with an annual capacity of 1 million head, and offered boxed beef under the label "Excel Country Cut Beef." Between 1975 and 1980 Cargill and IBP doubled their market share to 30 percent of beef slaughter, increased their share of the boxed beef market to 45 percent, and, with Cargill's Dodge City plant and IBP's new plant in Finney County, Kansas (1.2 million steers and heifers per year), owned the two largest slaughter plants in the world. ${ }^{31}$

The firm that Cargill outbid for MBPXL was the Omahabased company ConAgra, which, as the conglomeration trend continued into the 1980s, would be more successful at acquisitions. In addition to acquiring Monfort, Armour, and Swift, ConAgra even succeeded in acquiring Spencer Beef (the number seven packer in 1978) from Cargill, which had secured U.S. Supreme Court approval to purchase the company in 1986 over the objections of Monfort. The conglomeration trend even

30. Hughes Bagley, House hearings, Part 5, 5, 6, 9. John M. Fitzgibbons, Special Counsel to the subcommittee, quoted an internal IBP memorandum from Perry Haines (vice-president of scheduling at IBP) to Roy Zider (executive vice-president), 14 October 1975: "The mechanism to achieve it is the establishment of outside carcass suppliers. The epitome of this type source would be the small independent packer who has laid off his luggers and is locked into our operation via the tram.... This direction of buying in more and selling out more will increase IBP's participation in the market, and therefore market share and control." House hearings, Part 5, 11.

31. Skaggs, Prime Cut, 198; House hearings, Part 3, 27-30, 144-47; Donald D. Stull and Michael J. Broadway, "The Effect of Restructuring on Beefpacking in Kansas," Kansas Business Review 14 (1990), 13. 
involved IBP when it was acquired by Occidental Petroleum in $1981 .^{32}$

The success of the new firms stemmed partly from technology and transportation. Paul Bissell, who worked his way up from the kill floor in 1930 to beef department superintendent in 1956 at Morrell's Ottumwa plant, noted that until 1961, "as far as beef operations were concerned, little had changed back to the $30 \mathrm{s.}^{\text {.33 }}$ Soon, however, a "second technological revolution" introduced new devices such as stunners, mechanical knives and hide skinners, power saws, and electronic slicing and weighing equipment, all of which contributed to a productivity increase of 49 percent from 1960 to 1970. The new boxed beef process also dramatically reduced costs since, absent the whole carcass, only one-third as much weight had to be transported. These changes prompted the development of specialized plants that focused on one or two species, not four or five. The new plants required less capital, less labor, and cheaper labor, and allowed for more efficient use of technology, while older firms were stuck with the sunk costs of outdated plants. One economist estimated that such changes reduced the new firms' costs by as much as five to six cents per pound. Because the new packers were usually located close to cattle supplies, they also enjoyed lower transportation costs, while the emergence of the truck and an improved road system eliminated the advantage the old packers' links to a large rail network had given them. The use of trucks also made the new packers' marketing plans more flexible and, because they were a relatively cheap (compared to the railroad) capital acquisition, fostered market entry. In addition, the meat grading system devised by the federal government undermined the older firms' brand-name advantage, reduced marketing costs

32. In 1978 the top ten packers were IBP, Swift (Esmark), MBPXL (soon Cargill), Morrell (United Brands), Armour (Greyhound), Dubuque (privately held), Spencer (bought in 1978 by Land O'Lakes), Wilson (LTV, the world's largest hog slaughterer, which has closed all its beef plants), National Beef Packing, and Monfort. House hearings, Part 3, 34.

33. Warren, "When 'Ottumwa Went to the Dogs," 234. 
for the newer rivals, and increased buyer information about quality. ${ }^{34}$

Another competitive advantage potentially enjoyed by new firms involved the costs of cattle and hogs. During the years of the Big Four, 80 percent of livestock were marketed through terminal markets or local auction houses, where prices were set publicly and rivals knew each others' costs. By 1984, however, only 7 percent were marketed through the terminal markets, while many were vertically contracted by farmers or feedlots directly to the packer. IBP could, for example, underprice rivals by paying less for livestock in regional markets where the competition for supplies was reduced, which they were often accused of doing. Such occurrences prompted farmers to organize their marketing more thoroughly throughout the postwar period. ${ }^{35}$

The biggest advantage enjoyed by the emerging firms involved labor costs. The meatpackers that established operations in the rural grain belt, particularly in states such as Iowa, Nebraska, and Kansas, benefited from state right-to-work laws that passed after World War II. Previously, much of the meatpacking industry had been centered in Chicago, an urban environment more favorable to labor organization and therefore involving greater labor costs. ${ }^{36}$ The United Packinghouse Workers of America thought such moves purposely sought to take

34. Skaggs, Prime Cut, 189-90; Marion, Organization and Performance of the U.S. Food System, 131; Richard J. Arnould, "Changing Patterns of Concentration in American Meat Packing, 1880-1963," Business History Review 45 (1971), 26-27, 29; Danton, "Decline of an Oligopoly," 45; Willard Williams, "Changing Structure of the Beef Packing Industry," 11, House hearings, Part 4, 69; Yeager, Competition and Regulation, 239-41; Report of the National Commission on Food Marketing, 25; Aduddell and Cain, "Consent Decree," 363; Schlebecker, Cattle Raising, 190, 206; Edwin R. O'Neill (formerly president and chairman of Western States Meat Packers Association), House hearings, Part 3, 43.

35. Jon K. Lauck, "American Agriculture and the Problem of Monopoly: The Political Economy of Grain Belt Farming, 1953-1980" (Ph.D. diss., University of Iowa, 1997), 182-350.

36. Skaggs, Prime Cut, 193; Michael J. Broadway and Donald D. Stull, "Rural Industrialization: The Example of Garden City, Kansas," Kansas Business Review 14 (1991), 1. See also the essays in Stromquist and Bergman, eds., Unionizing the Jungles. 
TABLE 2

PACKING INDUSTRY MASTER AGREEMENT WAGES VERSUS IBP WAGES

\begin{tabular}{lccc}
\hline Date & $\begin{array}{c}\text { Master } \\
\text { Agreement }\end{array}$ & IBP Slaughter & $\begin{array}{c}\text { IBP Processing } \\
\text { (Boxed Beef) }\end{array}$ \\
\hline April 1970 & $\$ 3.94$ & $\$ 3.34$ & $\$ 2.74$ \\
October 1973 & 4.71 & 3.80 & 3.19 \\
February 1977 & 6.47 & 5.87 & 5.57 \\
October 1978 & 7.56 & 6.22 & 5.92 \\
October 1980 & 9.64 & 8.20 & 7.90 \\
October 1981 & 10.69 & 9.14 & 8.84 \\
\hline
\end{tabular}

SOURCE: Roger Horowitz, "Meatpacking as Paradigm? Labor and the Dynamics of Industrial Change in Twentieth-Century America," Research Seminar no. 15, February 1994, Center for the History of Business, Technology, and Society, Hagley Museum and Library, 14.

advantage of rural residents who "were not sensitive to traditions and concerns that had prompted the packing community's successful union-building. ${ }^{137}$

The new packers' labor arrangements contrasted sharply with the pattern bargaining that had developed across the meatpacking sector in the 1940s and 1950s, taking "wages out of competition." In the early 1960s, the older packers were paying about $\$ 1.15$ per hour more than their newer rivals. ${ }^{38}$ The master contracts also provided for automatic cost-ofliving adjustments, which triggered enormous losses during the stagflation of the 1970s and generated resentment among farmers and processors who thought they were wrongfully blamed for high food prices. ${ }^{39}$ The nearly total organization of meatpacking workers in the 1930s and 1940s had also dramatically increased worker involvement in plant decision making. At the Morrell plant in Ottumwa, for example, workers reached an agreement with management on the speed of the chain

37. Warren, "The Heyday of the CIO in lowa," 375, 383.

38. Arnould, "Changing Patterns of Concentration," 11.

39. Grey, "Turning the Pork Industry Upside Down," 253; Logan, Steinmann, and Farris, "Economics of Meat Processing," 251; Tracy Rhato to Earl Butz, 23 April 1973, and Oakley M. Ray (president, American Feed Manufacturers Association) to Richard Clark, 20 July 1976, Clark Papers. 
which determined the total number of animals to be killed in an hour. One worker at the Wilson plant in Cedar Rapids recalled that disputes over chain speeds "were probably the main reason for [work] stoppages" during that period. ${ }^{40}$

With the growth of nonunion firms, coupled with the technology that reduced the number of American meatpacking jobs from 274,000 in 1947 to 189,000 in 1972, workers' power declined. Only a few of IBP's plants were unionized, so, as one IBP official remembered, they could get by with the nonunion plants if a "labor problem" developed. For the most part, however, "management truly ran the plants ... and no restrictive agreements prevented the company from introducing productivity improvements." IBP's CEO Dale Tintsman admitted bluntly in 1980, "We're proud of our workers, but basically we can teach anybody to do a job in our plant in 30 days or lessthey don't need the skills of an old-time butcher who had to know how to cut up a whole carcass. ${ }^{\prime 41}$ Such was the strategy invoked in IBP's takeover of the Hygrade plant in Storm Lake, Iowa, in the early 1980s, the company's first large-scale move into the pork business. After buying the plant, IBP rehired only a few of the former union workers, recruited local union leaders to be part of management, employed enough Mexican and Laotian immigrants to constitute one-third of the work force, and paid one-half the wages the former Hygrade workers had received. ${ }^{42}$ IBP was also able to increase chain speeds by up to 80 percent in some plants. ${ }^{43}$ IBP's cost advantage grew when nonunion workers replaced union workers, mechanization increased efficiency and obviated the need for skilled workers in the plants, and, through the boxed beef process, the jobs of the specialized butchers of the grocery stores could be eliminated.

40. Warren, "When 'Ottumwa Went to the Dogs," 219; Shelton Stromquist, Solidarity and Survival: An Oral History of Iowa Labor in the Twentieth Century (Iowa City, 1993), 160.

41. "IBP and the U.S. Meat Industry," 12-13.

42. Grey, "Turning the Pork Industry Upside Down," 257-59.

43. Donald D. Stull, "Cattle Cost Money: Beefpacking's Consequences for Workers and Communities," High Plains Anthropologist 14 (1994), 64. 
The competitive pressures exerted by IBP caused tremendous difficulties for unionized plants; California packers, for example, complained that the "substandard wages" of firms such as IBP jeopardized their economic future. ${ }^{44}$ Hormel, with the highest labor costs in the industry at 18.7 percent of sales, compared to an average of 10.7 percent for the new packers, struggled through perhaps the nation's most bitter labor dispute of the 1980s at its Austin, Minnesota, plant. ${ }^{45}$ Some companies adjusted by following the IBP model. Swift, now a subsidiary of Esmark, shut down three slaughterhouses and paid the workers severance pay, spun off its fresh meat operation in 1981 into SIPCO (Swift Independent Packing Co.), then rehired the workers at a much-reduced pay level. ${ }^{46}$ In 1984 Greyhound released its Armour workers, paid their severance pay, then sold Armour to ConAgra, which reopened the seventeen plants with nonunion workers. ${ }^{4}$

The fierce competition of the 1960s and 1970s led to the emergence of a new set of large firms in the meatpacking industry by the late 1980s. By 1988, IBP, Cargill, ConAgra, and Beef America slaughtered 70 percent of American beef, well above the 52 percent concentration level of the Big Four in 1950. But reconcentration is not necessarily a sign of a decline in competition. When Monfort attempted to prevent Cargill's acquisition of Spencer in the mid-1980s, it did not argue that the merger would lead to monopoly, but that the increased competition could jeopardize Monfort's economic future. When allow-

44. Edwin R. O'Neill (formerly president and chairman of Western States Meat Packers Association), House hearings, Part 3, 43.

45. "George A. Hormel \& Company," Harvard Business School Case 9-591026, 7 May 1991, 3. See also Fred Halstead, The 1985-1986 Hormel Meatpackers Strike in Austin, Minnesota (New York, 1986); Hardy Green, On Strike at Hormel: The Struggle for a Democratic Labor Movement (Philadelphia, 1990); Dave Hage and Paul Klauda, No Retreat, No Surrender: Labor's War at Hormel (New York, 1989); Peter Rachleff, Hard-Pressed in the Heartland: The Hormel Strike and the Future of the Labor Movement (Boston, 1993); and the documentary film by Barbara Kopple, American Dream (Cabin Creek Films, 1990).

46. Skaggs, Prime Cut, 198.

47. Michael J. Broadway, "From City to Countryside: Recent Changes in the Structure and Location of the Meat- and Fish-Processing Industries," in Donald D. Stull, Michael J. Broadway, and David Griffith, eds., Any Way You Cut It: Meat Processing and Small-Town America (Lawrence, KS, 1995), 22. 
ing the acquisition in 1986, the U.S. Supreme Court concluded that Monfort "must show a threat of antitrust injury, and that a showing of loss or damage due merely to increased competition does not constitute such injury. ${ }^{\prime \prime 48}$

In 1992 the USDA commissioned a large-scale study of the meatpacking industry. The final report provided "no definitive evidence that concentration had an appreciable effect" on prices. A ten-year low in cattle prices in 1995-when cattle inventories were the largest since 1973, pushing cattle prices down 20 percent in 2 years-prompted farm groups to call for more antitrust investigations into the large packers. As a result, the USDA Grain Inspection, Packers and Stockyards Administration investigated the activities of ConAgra, Cargill, IBP, and Farmland in Kansas over a four-month period, including an analysis of procurement data, 10,000 cellular phone calls made by packer buyers, and 15,000 transactions, but found no evidence of collusion or anticompetitive practices. In the most recent round of discussions about the monopoly issue, an Iowa State University economist summarized the recent findings and, in so doing, forty years of meatpacking history: "Cartels don't hold up, because there is a tendency to cheat; and meatpacking is a cut-throat business. ${ }^{149}$

INCREASED CONCENTRATION of both the feeding industry and the food retailing sector, fluctuating demand, growing imports, and increased competition for supplies from farmers all limited postwar meatpackers' power to control the market. Even the industry "shake-out" from 1967 to 1982 indicated the continued vitality of competition within the industry, not its absence. The evidence of competition in the meatpack-

48. Cargill, Inc. v. Monfort of Colorado, Inc., 107 S.Ct. 484 (1986). Italics have been added. See also Emery McRill, "Private Party Injunctive Relief under the Clayton Act: Cargill, Inc. vs Monfort of Colorado, Inc.," Journal of Corporation Law 13 (1987), 145-68.

49. Des Moines Register, 20 May and 19 October 1995, 19 February and 19 June 1996; the economist John Lawrence is quoted in Business Record, 29 July 1996. The most useful of the government reports is Azzeddine M. Azzam and Dale G. Anderson, Assessing Competition in Meatpacking: Economic History, Theory, and Evidence (USDA, Packers and Stockyards Programs, May 1996). 
ing sector is an important cautionary tale calling into question assumptions among political theorists that concentration of economic power is an inevitable characteristic of "late capitalism. ${ }^{150}$ The slowing of antitrust activities in the 1980s, together with the conglomeration of food processing, remains a concern for farmers given potential abuses of market power and the often disorganized nature of farmer marketing. Yet in the three decades after World War II, meatpacking serves as an obvious exception to theoretical prognostications about the "evolutionary path" toward monopoly capitalism. More empirical studies of historical experience are needed to determine how representative the meatpacking sector is, but it seems to be part of a larger postwar economic trend toward competition and efficiency. The percentage of the economy defined as "tight oligopoly" declined by one-half from the 1950 s to the 1980 s, and "effectively competitive markets" defined three-fourths of national income by the 1980 s. $^{51}$ Given those conditions, concerns about concentration and conglomeration in the American

50. Scott Lash and John Urry, The End of Organized Capitalism (Madison, WI, 1987), 2; Paul M. Sweezy and Paul A. Baran, Monopoly Capital (New York, 1966); Joanne Barkan, "A Blast from the Past: Paul A. Baran and Paul M. Sweezy's Monopoly Capital," Dissent (Spring 1997), 95-101. Some see a steady increase in concentration as a central part of the story of the postwar economy: "A greater and greater share of the productive capacity of the economy -financial assets, physical assets, and labor power-has come under the control of those increasingly complex, hierarchically-structured, private bureaucracies called corporations." They then blame the economic stresses and structural change of the 1970s and 1980s on concentration. Barry Bluestone and Bennett Harrison, The Deindustrialization of America: Plant Closings, Community Abandonment, and the Dismantling of Basic Industry (New York, 1982), 119. For the importance of the idea of corporate power in postwar social science, see, for prominent examples, C. Wright Mills, The Power Elite (New York, 1957); Gabriel Kolko, Wealth and Power in America: An Analysis of Social Class and Income Distribution (New York, 1962); G. William Domhoff, Who Rules America? (Englewood Cliffs, NJ, 1967); John Kenneth Galbraith, The New Industrial State (New York, 1968); and John Bellamy Foster, The Theory of Monopoly Capitalism: An Elaboration of Marxian Political Economy (New York, 1986). For the debate over corporate control of state decision making, see, for example, Theda Skocpol, Bringing the State Back In (New York, 1985); and G. William Domhoff, State Autonomy or Class Dominance? Case Studies on Policy Making in America (New York, 1996).

51. William G. Shepherd, "Causes of Increased Competition in the U.S. Economy, 1939-1980," Review of Economics and Statistics 64 (1982), 624. 
economy might be better directed at the consequences of competition, not monopoly, and at stimulating debate about the tradeoffs between an efficient and competitive economic arena and a decentralized economy more conducive to the survival of small businesses. 
Copyright of Annals of Iowa is the property of State of Iowa, by \& through the State Historical Society of Iowa and its content may not be copied or emailed to multiple sites or posted to a listserv without the copyright holder's express written permission. However, users may print, download, or email articles for individual use. 